\title{
Living on Borrowed Identity: Negotiating the challenges of Sri Lankan Pirivena education and upholding the identity as Buddhist monks
}

\section{Nirosha Ruwanpathirana*, Samitha Udayanga, BKD Lakmali}

\section{Abstract}

The Buddhist education system was well integrated into the Sri Lankan intelligence tradition for millennia. However, its importance had been severely declined soon after the lay-focus missionary education system was established in Ceylon (Sri Lanka) during the British colonisation. Because the government of Sri Lanka mainstreamed and facilitated a lay-focused education system as a priority welfare concern, the Pirivenaeducation system has been neglected and under facilitated. However, the contribution of the Pirivenais still essential for student-Buddhist monks because their education relies on the Pirivenaeducation system substantially, but it encounters certain challenges in the modern-day. Therefore, this study seeks to identify certain challenges Buddhist monks encounter when they learn in Pirivenas while striving to establish a sound relationship with the lay society, simultaneously upholding their identity as Buddhist monks. A qualitative case study design was employed for this research, and thematic analysis was applied. The analysis indicates that the internal culture of the Pirivenaeducation institution has important implications for Bhikkhu's education. The influence of the unique hierarchical organisation of power and authority with educational institutions is also recognised as critical for education among student Buddhist monks. Conscious behavioural changes during the transition from laity to monkhood is another crucial determinant that causes challenges in Pirivenaeducation. Overall, it is argued that there is an urgent need of revising the existing Pirivenaeducation system whilst reflecting the dynamics of changing Sri Lankan society.

Keywords: Behavioural Changes, Novice Buddhist Monks, PirivenaEducation, Reflective Identity, Subculture

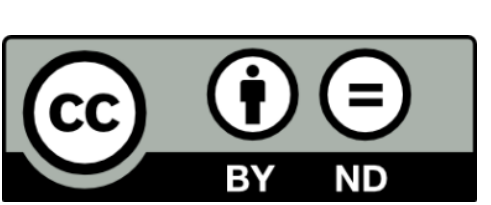

This article is published under the Creative Commons CC-BY-ND License (https://creativecommons.org/licenses/by-nd/4.0/). This license permits to use, distribute, and reproduce the contents of the publication for commercial and non-commercial purposes, provided that the original work is properly cited and is not changed anyway. 


\section{INTRODUCTION}

The Buddhist education tradition is pedagogically sound and well organised among many other education systems in Sri Lanka (K. M. de Silva, 1981; Rhea, 2012). The Buddhist education system facilitates both Buddhist monks and male-laities to become well-disciplined persons (Adhikari, 1993). Traditionally, the education of Buddhist monks had been a matter of studying under olderintelligent-well-disciplined monks (Sthavira) within monasteries, and the way the knowledge is transferred was uniquely well-contextualised (Scott, 1996). Buddhist monks are the disciples who adhere to norms and principles of Buddhism while practising Dhamma to attain Nibbana (Hori, 1996). The Buddha designed an organisation that facilitates people to achieve the most happiness possible while enabling them to emancipate themselves from narrow world views (Dhammajothi, 2020). Theoretically, when a laity ordains as a monk, he is expected to adjust his behaviour in line with the Buddha Sasana(Buddhist Tradition) that consists of several disciplinary codes and specific ways of lifestyle that entirely distinguishes them from lay-society, which importantly helps them to achieve spiritual well-being and ultimate Nibbana. Buddha Sasanais considered to be a place where a person can obtain Vimukti or Nibbana, and hence the practices toward that great end are different from that of lay-societalnorms (Wangmo, 2016).

The utmost and intrinsic dedication is required to achieving Nibbana, and thus existing lay lifestyle has been considered irrelevant within the Buddha Sasana. However, Buddha Sasanahas been changed during the past few decades due to global social changes. Therefore, the ideal lifestyle of Buddhist monks has gradually changed, sometimes even incorporating lay practices. Monastic education has traditionally been wellaligned with Tripitaka (Theravada Buddhist Books) in ancient Sri Lanka (C. de Silva, 2019), however after the British colonial period, with the introduction of western-dominant education systems, the purpose and the very nature of the education of Buddhist monks had been changed (Kloppenborg, 1984). Becoming a monk in the Buddha Sasanais critical, as the lay persona is entirely transformed while incorporating an unfamiliar lifestyle and identity thereafter. When a laity becomes ordained as a novice monk (samanera), he must undergo several behavioural modifications while living on a newly acquired identity corresponding to a specific code of disciplines (Vinaya). Therefore, the main intention of this study is to inquire how novice Buddhist monks in Sri Lanka undergo behavioural modification in the process of becoming a complete Buddhist monk (Upasampada) and how they deal with 
some challenges might encounter in their education.

\section{LITERATURE REVIEW}

Monasteries had been educational institutions for both Buddhist monks and male-laities in ancient Sri Lanka (K. M. de Silva, 1981). Since Buddha Sasanaallows both male and female laities to get ordained, both male and female laities of Sri Lanka are ordained in the Buddha Sasana. Monasteries were constructed and facilitated by the government in Sri Lanka as a great responsibility of the king (Amarasekara, 2017; Rahula, 1956). Some higher educational institutions were gradually constructed in ancient Anuradhapura (the first capital of Sri Lanka), and they had become internationally well-recognised institutions (Bandaranayake, 2009; C. de Silva, 2019; Rahula, 1956). Until the colonisation of Sri Lanka, the monastic education system was progressively operated in the country, but after the colonial period, some profound changes occurred in monastic education (C. de Silva, 2019; Dhammajothi, 2020). During the European colonisation of Sri Lanka, not just the Buddhist education system but the Buddha Sasanawas disrupted and hence the quality of education of Buddhist monks was declined (Barua,
2014; Karunarathna, 1974; Mendis, 1952; Wenzlhuemer, 2008). However, during the religious revival movement, some notable Buddhist Monks such as Hikkaduwe Sri Sumangala (depicted in Figure 1)and RatmalaneDharmalokaestablished

Buddhist Monks' education institutions named "Pirivena" (Andradi, 1967; Jayaram, 1994).

Scholars believe that the historical pathway to establishing a formal Bhikkhu Pirivena education dates back to the nineteenth and twentieth centuries (K. M. de Silva, 1972; Mendis, 1952; Rahula, 1956). History testifies to the fact that the educational institutions of the monks have existed from very early times. Before the Christian era, Buddhist educational institutions in Nalanda, Thakshila and other centres in India operated as Buddhist educational institutions (Basham, 2004; Thapar, 1973). Buddhist education has a long history dated back to the third century B.C. As shown in the history of Sri Lanka, there were three main Buddhist educational centres disseminating knowledge on a wide variety of disciplines related to Buddhism. They are Maha Vihara ( $3^{\text {rd }}$ century B. C), Abhayagiriya Vihara ( $3^{\text {rd }}$ century A.D) and Jethawana(Keerthirathne, 2020; Rahula, 1956). 


\section{Original Article}

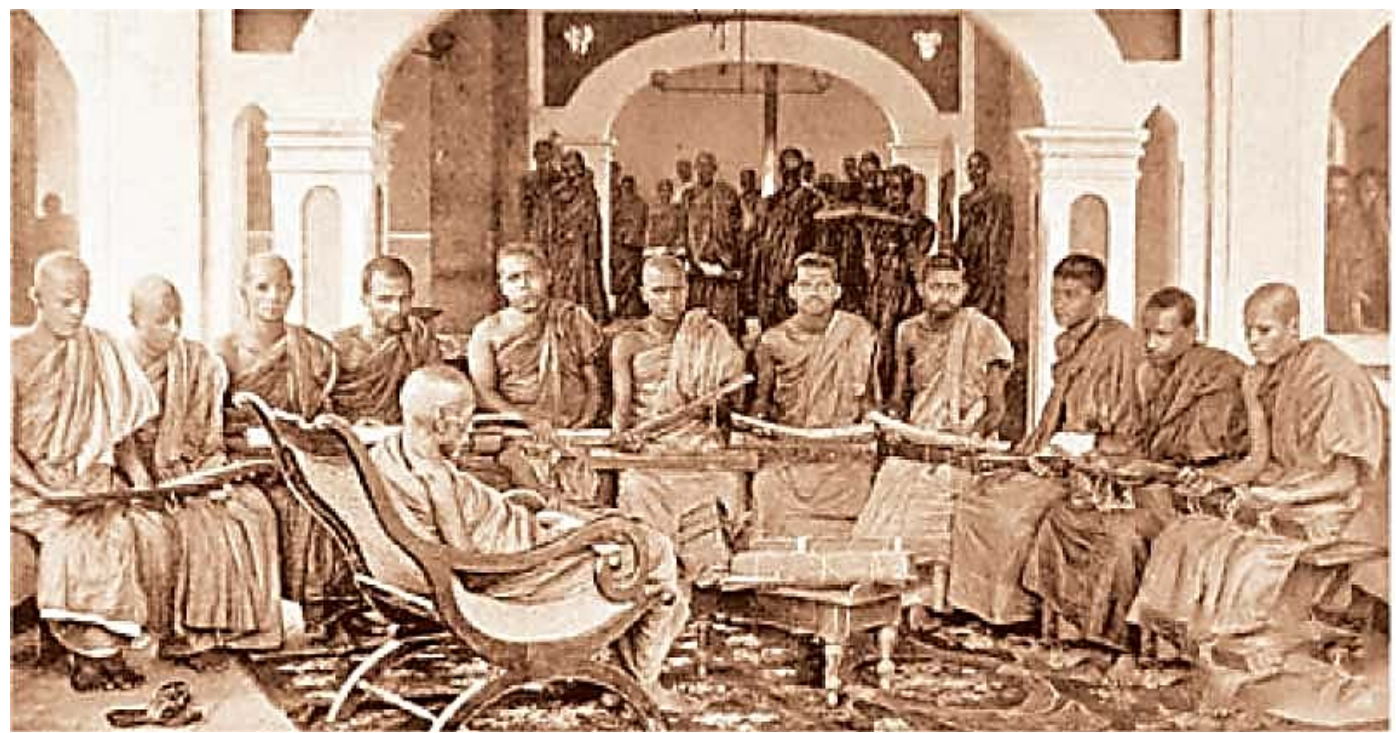

Figure 1: Ven. Hikkaduwe Sri Sumangala Nayaka Thera instructing a class at VidyodayaPirivena in Maligakanda, Colombo.

(Source: https://www.dailynews.lk/2021/04/29/features/247799/giant-behind-revival-buddhism)

It is worth mentioning the vision and mission of Pirivena education as this study focuses on the problems faced by student Buddhist monks in their education. The Pirivena Education Branch of the Department of Education notes the mission as to create a good and disciplined group of monks. The vision of Pirivena education is "to create a Bhikkhu council while preserving the tradition of Sri Lanka's classical education and to produce citizens with knowledge, attitudes and skills that suit contemporary needs".In Sri Lanka, centres of learning grew up in the major monastic centres such as the Mahavihara, Thuparamaya and Chetiya Vihara. All of them were autonomous educational institutions, but from at least the seventh century of the Christian era to about the $15^{\text {th }}$ century, each centre belonged to one or the other of several scholarly traditions that were established through key institutions (Chandra, 2019).

The Pirivenaeducation has also been one of the Buddhist education systems in Sri Lanka, where Buddhism was studied thoroughly. Historically, the Pirivenaeducation had been given an important place (K. M. de Silva, 1981). These education institutions were not just schools but functioned as modernday universities (Keerthirathne, 2020). The curriculum of Pirivenaincluded but was not limited to Buddhism. Sometimes, lay disciplines were included in the curriculum. However, the primary consideration was Buddhism (Tripitaka). In 1980, the parliament passed the act on Pirivena Education that recognised four purposes: 


\section{Original Article}

a. To foster an interest among Bhikkhus in the protection and progress of the threefold Sasana namely, Pariatti, Patipaththi, Pativedha;

b. To foster discipline, knowledge in the Tripitaka and devotion to Dhamma among Bhikkhus in order to maintain the order of Bhikkhus designing from the lineage of Sariputta and MoggallanaMahaTheras;

c. To give training in practical knowledge necessary for the Dhamma Dhutha activities in Sri Lanka and abroad;

d. To provide facilities for Bhikkhus to acquire a thorough knowledge in various subjects and languages including Buddhist Philosophy, Buddhist Culture, Buddhist History, Pali and Sanskrit (Pirivena Education Act, 1980).

The education of the Buddhist monks consists of both formal and informal learning components. Informal learning involves referring to Tripitaka books, going along with instructions of senior Buddhist monks to memorise verses, character narratives, and learning the Pali language, socialisation, and interaction with peers. Pirivena education is significant in discussing the formal education of the Buddhist monk.

According to Article 8 of Part III of the Privena Education Act No 64 of 1979, there are several primary objectives of a Mulika Pirivena: classes from Pirivena Grade I to Pirivena Grade V shall be conducted in a MulikaPirivena; a MulikaPirivena shall be a residential educational institution providing classes for Bhikkhu residents in the Mulika Pirivena; in the curriculum of a Mulika Pirivena the teaching of the traditional Pirivena curriculum and the training of bhikkhus according to the Vinaya rules shall be given a foremost place; and the Commissioner of Examinations on the advice of the Board may, at the end of the course of studies in a MulikaPirivena, hold an examination for pupils of a Mulika Pirivena. Article 9(2) discusses the role of MahaPirivena: classes for the examinations held by the Oriental Studies Society and for any other examinations with a similar curriculum approved by the Board shall be conducted in a MahaPirivena.

This act comprehensively recognised the need of providing proper, quality and relevant education for novice Buddhist Monks in the protection and progression of the threefold Buddha Sasana. However, the expectations of the time of passing the above act have now been modified largely due to several sociocultural, economic and political reasons. The very reason for ordination has now been changed. The Buddha expected the disciples/monks to adhere to a certain set of disciplinary codes, even though now some Buddhist monks are highly likely to live as most closely to lay-life style. Therefore, Buddhist monks undergo a certain set of challenges when they strive to learn in modern 


\section{Original Article}

Pirivenaand to dealing with the lay society. This study thus seeks to identify certain challenges Buddhist monks encounter when they learn in Pirivenas while striving to establish a positive and stable relationship with the lay society, simultaneously upholding their identity as Buddhist monks.

\section{METHODOLOGY}

Identifying the challenges of Pirivenaeducation of Buddhist monks in Sri Lanka was the main objective of this study. Challenges faced by student-Buddhist monks, particularly in their Pirivenaeducation were strived to be identified as reflected by Buddhist monks themselves, so that we decided to employ an interpretative phenomenological analysis for this study. Exploring how individuals make sense of their personal and social world has been the main aim of Interpretative Phenomenological Analysis (IPA) (Smith \& Osborn, 2015). Education is considered to be lived experience among Buddhist monks within the limits of lifeworld constricted into Sangha Sasana.

\section{Study design}

We employed a holistic single case study design in our study; therein the main context of the case was considered having Buddhist monks who are still learning in Pirivenasor have completed their Pirivenaeducation. We recruited some
Buddhist monks purposively, and then the snowball sampling technique was employed to recruit informantladen participants to the case. Each participant took part in a semistructured interview conducted between August-2020 to January 2021. First, we have constructed some questions to ask from Buddhist monks to reveal issues of education in Piriveaneducation. Mainly our focus was three-fold: How Buddhist monks reflect challenges, how challenges of education for Buddhist monks can emerge within the complex relationship between secular society and the Sangha community, and how Buddhist monks respond to those challenges. The questions were based on the above concerns and ultimately, we strived to understand different challenges faced by Buddhist monks in their Pirivenaeducation. We considered Buddhist monks having a specific behavioural pattern unlike laity as education has become an essential element of their lifeworld. The semistructured interview guideline was piloted with a group of experts before interviews were conducted. The design of this study was based on the consolidated criteria for reporting qualitative research (Tong, Sainsbury, \& Craig, 2007).

\section{Participants}

We used the purposive sampling technique first to recruit respondents for this study, which involved selecting participants who share common and some particular 


\section{Original Article}

characteristics and have the potential to provide rich, relevant and diverse data needed in the research. Those who are still studying in Pirivenasand those who have completed Pirivenaeducation were selected purposively. Sometimes participantladen (snowball sampling) individuals were selected. Overall, ten Buddhist monks were interviewed. Sampling was terminated in accordance with the theoretical saturation principle (Morse \& Clark, 2019). Besides, recently disrobed persons were selected as they have the potential to provide much richer data on some serious issues of Pirivena education than those who are still in the system.

\section{Data Collection}

Participants were interviewed using a semi-structured guideline that focused on three areas as described above. Interviews lasted between thirteen to forty minutes and were audiorecorded once the informed consent was obtained. In parallel, a member of the research team jotted down some context-specific specifications. Audio recordings were then transcribed verbatim. Some participants joined the interview online, whereas some were interviewed at their locations and on the university premises. Concerns of the interviews included exploring reflections about their disposition in the society, challenges as reflected by Buddhist monks and complex relationships between laity and Bhikkhu community.

\section{Analysis}

Data were analysed employing six steps-thematic analysis approach (Braun \& Clarke, 2006). First, we familiarised ourselves with transcribed data. We read all transcriptions and discussed them within the research team. Next, we generated initial codes through open coding. Codes were then axial coded to construct initial themes. Developed themes were then reviewed carefully within the research team. The next step was to define and name the themes. Generally, we identified five themes that directly discuss different challenges of Buddhist monks' education in Sri Lanka. Finally, we related analytic narratives and theoretically valid themes to present thematically.

\section{FINDINGS}

\section{Education System of the Bhikkhus}

Several obstacles can be identified with Pirivenaeducationwhen the Act is in operation. We were able to identify some concerns such as contemporary relevance of the existing syllabus, absorbing English knowledge and computer literacy. Furthermore, exposure to global knowledge and awareness have been minimum. Novice Buddhist monks often engage in informal learning within their residing temples. They receive this through practising sermons, memorising verses in Pali, and 


\section{Original Article}

DOI: http://doi.org/10.4038/jsshr.v6i1.78

through their senior Buddhist monks. Thus, the contribution ofPirivena education is important as a formal learning system. However, a number of challenges are present in this formal education system. For example, student-Buddhist monks are less likely to receive global knowledge and awareness adequately.

"We like to learn diverse subjects that are contemporarily revenant in the world today. But we are compelled to learn what the Pirivenateaches us. I think these syllabi need to be upgraded. If not, we won't be able to see progress in the Bhikkhus." (In-depth interview 03)

Based on the qualifications obtained through education, there are several categories of young Buddhist monks: Upasampada, graduate, advanced level qualified, Pirivena final grade qualified, oriental qualified and not educated. We understood that syllabi of formal education within Pirivena need revisions incorporating some contemporary relevant disciplines. However, Pali, Sanskrit, Art, Buddhism should be made compulsory, and that the process should be more convenient as the Pirivenaalready provides learning experiences related to the tradition of memorising. Furthermore, the education of Buddhist monks more often does not involve private education. There is no enthusiasm for subjects such as English and Information Technology, and constricted into a few subjects can be considered shortcomings in the Pirivenaeducation today.

Buddhist monks who complete Pirivenaeducation tend to complete tertiary education in the same field as they do not intend to change their way of learning and discipline.

"Lack of diversification of
subjects is a limitation in
Pirivenaeducation. Even at the
graduate level, we learn subjects
such as Buddhism, Pali,
philosophy, and history. Had we
learned diverse subjects in
Pirivena, it would have been very
advantageous to us in the post-
Pirivenaeducation." (In-depth
interview 05)

It is also important to note that Buddhist monks receive a comparatively low level of experience in the English language and computer literacy to gain global knowledge. Participants asserted that there is a lack of scholarship opportunities and even the few that are offered received by urban Buddhist monks.

"Young Bhikkhus need knowledge on English, technology and computer literacy. It would be a positive contribution to society if we can preach Dhamma in English. Bhikkhus needs this knowledge to bring social harmony, reach a global base, and bring honour to the country. For example, if we can preach Dhamma in Tamil, 


\section{Original Article}

reaching the Tamils will be more effective. So young Buddhist monks can contribute as a leading force in resolving ethnic issues and reducing inequality." (Indepth interview 05)

The Pirivena education should be aligned with the global direction, and now some initiatives have been taken even though the progress is slow. Furthermore, some Buddhist monks are likely to complete up to Grade three and five and often unable to undertake university education (although they are eager to receive it) owing to financial issues.

The participation of Buddhist monks in private tuition classes is not as same as lay students'. Participants of the research revealed that most Buddhist monks receive notes and study materials from lay students. Generally, participation in some private tuition classes particularly during the advanced level might increase with some limitations, as Buddhist monks encounter different challenges when they learn together with lay students whose lifestyle is entirely different from that of Buddhist monks.

During the early years of Pirivenaeducation, the need to participate in private tuition classes was not mandatory or a necessity, except for English language classes and Computer literacy classes. However, Buddhist monks preparing for Advanced Level examinations aiming at university education are likely to attend private classes dominated by a lay curriculum.

Buddhist monks' education is generally two-fold: one can learn oriental subjects as an oriental scholar, whereas some can choose to learn for university entrance. Oriental education is largely predominated by some subjects such as Pali, Sanskrit, Sinhalese and Buddhism. Some Buddhist monks choose to go on that path, while many now choose to go on advanced level education, leading to university higher education.

Therefore, participants of this study are strongly on the opinion of an immediate syllabus revision.

"Frist, Pirivenaeducation needs to be restructured. Lay students have a formal education system from Grade 1 to university level, although there are minor shortcomings in it. But not so for Bhikkhus. Although there are Mulika Pirivena, MahaPirivenaand PirivenaVidyayathanaya, the functions of these institutions are lagging" (In-depth interview 07)

Thus, the unchanged and long used syllabuses for Buddhist monks studying in Pirivena have been recognised as one of the main challenges that must be revised immediately.

\section{Behavioural changes in monastic life}

When a person becomes a Buddhist monk, the generic role of that person is 


\section{Original Article}

supposedly changed. Transforming the existing behaviour of the lay life world to a sacred one is difficult as people are accustomed to ordinary secular life for a long period. A Buddhist monk is highly esteemed by his parents, family members and members of the community. There are a number of unique activities and procedures to be followed. At the same time, the monk has a social responsibility, and society too expects the monk to play certain recognised roles. For example, waking up at around 4.30 am followed by practising pirith and learning different Buddhist books can be challenging. As we studied, the transformation of a secular person to a clergyman can create several challenges. Today, young Buddhist monks face many problems due to their lack of knowledge in Dhamma, lack of understanding in dealing closely with people and social acceptance. Even though the path of the Buddha is followed while upholding the precepts of discipline, there are many occasions when a monk is criticised instead of gaining more respect in society because of modern education.

It should also be pointed out here that the monk became independent with the nobility. Intimate relationships can hinder a person's pursuit of their desired goals, but within the Buddha Sasana, being a monk means building some mundane relationships to serve society. Thus, we assert that when a novice Buddhist monk is mature, changed behavioural models can cause different conflicts. As a monk moves up in the hierarchy of the Bhikkhu education, the monk is likely to tempt to pursue his professional and educational needs compromising what is expected from a Buddhist monk traditionally. Today the responsibility of being a Buddhist monk has been critically discoursed by society. When Buddhist monks strive to uphold given responsibilities while adopting new behaviours aligned to education would cause role conflicts preventing each responsibility sphere's success. "Should a Bhikkhu dedicate his life entirely to make others' lives better"? As this statement indicates, now Buddhist monks encounter great difficulty in balancing personal desires and social responsibilities.

"I studied hard as a monk, and today I am a lecturer. Today I am at the top of bhikkhu education. Although a layperson could have changed from lay life to sacred life it consists of role conflicts. I can't stop avoiding things like the Bodhi Pooja, Seelawiyapara while moving up with professional aspirations." (In-depth interview 06)

As the status quo changes from this secular life to sacred life, the monk has to act in accordance with a number of precepts that are generally accepted by society.

"The laws of the Buddha were historically appropriate. But those laws are not applicable today. But 


\section{Original Article}

we have no right to criticise it. It is very difficult to treat the body as the Lord Buddha said because it is naturally adapted to reproduction". (In-depth interview 08)

Although education in secular life is very difficult, engaging in education as a Buddhist monk becomes a very simple activity for some persons. As we recognised, some weak students are likely to perform well when entering into the Buddha Sasana while adopting new behavioural changes. Sometimes societal issues prevent lay students from learning successfully, but within the Pirivena, they are learning successfully due to the support given by the residing temple and peers.

"I was not good at learning when I was schooling. But after becoming a Buddhist monk, I was able to listen to sermons and Pirith chanting. I realised that it was not as difficult as I used to think in concentrating my mind to perform a concerning activity well". (Indepth interview 02)

This shows that some laities become well acquainted with Pirivena education after becoming a Buddhist monk because the temple environment well supports them.

The hierarchical arrangement of Pirivena and its influence on the education of Buddhist monks
The hierarchical arrangement of the general Sangha community and within the education system is rigid, in that power and responsibilities are assigned to different positions, which increase personal power. Personal power sometimes jeopardises the young Buddhist monks' education. Because the authority of the educational institutions is granted to a particular person, that person is more often exert his power in Sangha management. Inherently, the Sri Lankan Sangha community has been organised hierarchically and represented even in the Pirivenaeducation institutions. Three main chapters of the Sinhalese Buddhist community have been arranged into three chapters or sections based on the caste origin (as a very recent development), as we have noted in the introduction. Based on the same caste lines, some Pirivenasare organised. Therefore, some Buddhist monks are not allowed to enter into some Pirivenamanaged by different chapters (nikayas).

"Caste and power are not limited to lay society. That can even be seen in the Bhikkhu society. Thus, diversity in the form of separate temples, different colours of robes, and the way we dress can be seen." (In-depth interview 10)

Thus, it can be seen that dynamics such as respect, power and hierarchy can be seen even in the Sangha community. We strive to describe how these caste divisions and hierarchical 


\section{Original Article}

arrangements affect education among Buddhist monks.

Sometimes certain disturbances for education are identified in Pirivenainstitutions due to certain destructive forces including abuse and violence against free will. Some have had experiences of punishments and physical violence in some instances. Young Bhikkhus must obey the instructions of senior Bhikkhus, such as participation without denying in almsgiving, Pirith chanting, and funeral rites that the senior Bhikkhus had accepted. Conflicts may arise in declining to obey such instructions; thus young Bhikkhus are morally binding to the instructions given by senior Bhikkhus.

"Pirivenais a hierarchically
arranged institution. There are
multiple strata. Power is
distributed among these strata. It
can be a simple observation for an
outsider that a student-Bhikkhu is
studying. But only the Bhikkhus
know about the internal conflicts
and influences and divisions." (In-
depth interview 08)

The divisions are based on seniority, the chapter (Nikaya) where one ordained, and the social status before the ordination.

Several powerful positions within the Pirivena education system are noted, and it could be seen that hierarchical relations are built on individual actions. There is a manager of the
Pirivenaappointed by the DirectorGeneral. The Manager is usually the Chief Incumbent Bhikkhu of the temple where the Pirivenais located or someone recommended by the Chief Incumbent Bhikkhu. In other instances, the Director would appoint a suitable Bhikkhu. The Manager is tasked to oversee the chief incumbent and the teaching Bhikkhus and the administration and maintenance of Pirivena. The hierarchical arrangement of a Pirivenais demonstrated in Figure 2.

Director of Pirivena

(Pariwenadhipathi)/Chief Incumbent

Deputy Director of Pirivena

Chief of the Pirivena

Teachers

Students (Both Lay and Ordained students)

Figure 2: The hierarchical arrangement of a Pirivena

The power vested in each high ranked position has sometimes threatened the lower strata. In some cases, the positions of the chief incumbent and the Director of Pirivenaareassigned to one Buddhist monk who then holds an enormous level of power in administering the education institution. As some Buddhist monks explain:

"Director of Pirivena holds an extreme power who owns the institution, and his words are final. No one would be able to resist 


\section{Original Article}

what this director says." (In-depth interview 09)

Student Bhikkhus have to perform several tasks assigned by Senior Bhikkhus who are not directly involved in the education of the Pirivenain some situations, such as taking more time to almsgiving and Pirith chanting with senior monks, conducting Bodhi pooja and sil programmes. When student monks do not comply with these, they might be harmed physically and mentally as some novice monks specified, even though this does not often happen. Furthermore, the participants revealed that competing for leadership is common in certain temples. As the indepth interview 10 explains:

"Most of the time, the chief incumbent appoints someone friendlier to him or related to him as the leader. This leads to constant conflicts."

Therefore, according to the participants' responses, a hierarchy within the Pirivena education can be seen. An internal subculture has evolved within this hierarchy. The internal subculture has caused stratification, and power relations are important in this regard. Although senior Bhikkhus are expected to mentor the younger Bhikkhus into areas such as gaining merit, inculcating some skills to perform religious rituals, and temple administration, in practice, there can be some challenges involved. For example, they are unable to complete education activities when they engage in some customary practices in the temple (attending funerals, conducting Bodhi Pooja).

Dynamics of education among the Buddhist monks

Some dynamics might influence a person when entering Buddha Sasana from being a layperson in multiple ways. A clash in roles is prominent. They take over several new roles, such as being a Bhikkhu of a temple, a student Bhikkhu of a senior Bhikkhu, a student of a Pirivena, and an advisor to the lay community.

"We have limited freedom. We have to follow what the Chief Incumbent of the temple advises. They make us do a lot of religious activities. We cannot normally decline them." (In-depth interview 06)

It is, therefore, clear that the conflict in roles and responsibilities has now intensified. Although poverty has been one of the main reasons to ordain (as some participants assert), nowadays more and more laities enter Buddha Sasana with a clear understanding of the reality of life. Notably, there is a gap between rich and poor monks even within the Sri Lankan Bhikkhus community. However, some of the Bhikkhus in urban temples are well off than their counterparts in rural temples. Therefore, there is a significant difference between the 


\section{Original Article}

daily routine of young urban Bhikkhus and young rural Bhikkhus. As we have found, the young urban Bhikkhus are likely to receive rich support for education, whereas Buddhist monks in rural areas are less likely to. Some Buddhist monks in the urban areas are generally compelled to use some modern facilities like mobile phones, computers, and the internet, which influence increased behavioural modification among those Buddhist monks.

Controlling human desires as a Buddhist monk with the utmost endeavour toward Nibbana does not imply an absence of desire toward sex and attraction toward the opposite sex. They pointed out that they control their minds under great difficulty. In addition, the tasks of Bhikkhus have become distorted today and have expanded into various areas. Bhikkhus are likely to achieve social respect by becoming popular and receiving certain privileges. The lay community venerates them. It can be observed today that student Bhikkhus in the universities have surpassed their social expectations and have entered into student politics.

"The role of the Bhikkhus has evolved in line with the modern society. It is not a decline. We all are living in a modernising world, and our lifestyles evolve with it." (In-depth interview 10)

The use of social media is common among young Bhikkhus today, and according to the participants, it shows how modernisation has affected even the Bhikkhu community. They showed that young Bhikkhus sometimes have to go beyond worldly life and disrobe because of the difficulties of practising the spiritual qualities of the Bhikkhuhood. They showed that when social interactions are reduced, they get isolated and seek to find independence. This leads to the question as to whether Buddhist monks should only strive to fulfil the primary expectations of society.

Subculture, reflective identity and education of Buddhist monks

Culture is perceived both as an ideational system and an adaptive system of living. Culture as an ideational system provides a relatively stable and solid set of norms that govern behaviour, whereas culture as an adaptive system incorporates some changing aspects of society. The Buddhist monk community is one of the sub-communities of Sri Lanka that has a specific subculture that distinguishes Buddhist monks from the outside community. A religious community holds two distinguishing subculture qualities: Prestige and Invisibility. Since Buddha Sasana has long been honoured with utmost devotion by the Sri Lankan people, Buddhist monks are considered sacred and revered the most. Therefore, the prestige of the Bhikkhu community has been recognised as one of the distinguishing features of their subculture. Invisibility is another 


\section{Original Article}

characteristic of this subculture, in that the internal mechanism of the organisation is supposedly not visible to the outside. Both prestige and invisibility of the Sangha community construct a prestige based identity which uncompromised within the lay community.

\section{"Everyone reveres us. No matter what, any person with any rank reveres us. We are being nourished by the public so that we preach Dhamma to please them. Preaching Dhamma is vital to understanding the real nature of society. People are often highly obedient in front of us". (In-depth interview 07)}

Historically the prestige and invisibility gave the Sangha Sasanathe highest position in the social hierarchy of society, but now these characteristics may pave the way for challenges within the PirivenaEducation. Even though the Act of Pirivena Education proclaims the importance of educating Buddhist monks in line with Tripitaka, now they are being educated with lay-relevant disciplines such as information technology, mathematics and Basic Science. This is because of the belief that the Sangha community as an integral part of the changing society requires to have contemporary learning capacities. Some of the Bhikkhus in the modern-day Sangha community do not entirely dedicate themselves to obtaining Nibbana, and they engage in many different layrelated activities. Therefore, they strive to learn different subjects other than Buddhism. When they strive to learn lay-related disciplines other than Buddhism, student-Buddhist monks have to seek help from the lay community even in the education process previously supported by monks.
"When we go for a tuition class, we always think about some fashions done by boys. We, as human beings are attracted to them. Disciplining our behaviour is very difficult. There is a cultural shock when we expose to the lay world. Therefore, we again try to think about the desires of Buddhist monks and lay society." (In-depth interview 05)

Cognitive prestige has been another internalised mental schema that prevents Buddhist monks from obtaining a proper education. The Sangha community is considered the topmost layer of society's social hierarchy, and Buddhist monks are greatly revered. When novice Buddhist monks socialise within the sangha community, they tend to construct an internalised prestige mentality so that they believe that the lay society should honour them. Internalised cognitive prestige has been crystallised when Buddhist monks are engaged in some lay activities. For example, the arrival of Buddhist monks in funeral rituals is very important as people believe that the last rituals must be performed by sacred persons so that the dead person 


\section{Original Article}

can go to a happy place in the afterlife. The importance of Buddhist monks is represented even through some symbolic representations. Many rites of passage rituals are related to some religious activities through which Buddhist monks intervention to lay life has been encouraged. They are likely to develop a mindset that always seeks honour from the outside community through these processes. One of the respondents replied, "A seat in the bus is always reserved for us wherever we travel". This represents the honour expected from the outside community by Buddhist monks in contemporary Sri Lanka. This internalised cognitive prestige might sometimes deflate their education, as they have to learn from lay-teachers.

The same respect and honour received as a Buddhist monk cannot be expected when striving to achieve educational goals parallel to the lay community. However, some Buddhist monks are likely to expect the same respect from the lay community, but the lay community is reluctant to provide it as they cognise that now Buddhist monks are the same as the lay community.

Subculture among Buddhist monks includes some camouflaged practices which are not apparent to the outside. Even though the Buddha specifically asserts the baselessness of caste and regional differences in the Buddha Sasana, after the colonial period of Sri Lanka, the Sangha community was organised with caste and regional lines to some certain extent. For example, in SiyamNikaya(one of the sects in Buddha Sasana in Sri Lanka), caste purity is highly sought from novice Buddhist monks when promoted to the upasampadastate. If one line of parents shows an impurity, the upsamapadastate was not given.

"I had no idea about my caste when I was ordinated, but it was sought when I requested to become a complete Buddhist monk (upasamapada) from the organisation. Then I understood that my caste did not match with the Nikayathat I was belonged to. Therefore, the Sangha community strongly refused to give me upasamapada. After that, I faced severe difficulties, even to live in a monastery". (In-depth interview 09)

As the Buddha enumerated, the guidance from anAchariyaand Upadhyaya for novice Buddhist monks are essential. The same system has been applied in Pirivenaeducation, but the personal qualities of those leaderBuddhist monks sometimes negatively influence the student- Buddhist monks' education.

\section{CONCLUSION}

The education system in Sri Lanka dates back to several centuries and has been greatly influenced by Buddhist education traditions. From its 


\section{Original Article}

DOI: http://doi.org/10.4038/jsshr.v6i1.78

inception, the education of citizens has been given a considerable place in the Sri Lankan civilisation, and the contribution toward that by the Buddhist educational institutions has been widely pronounced. Before the European colonisation of the country, Buddhist institutions provided education mainly for Buddhist monks and male-laities. Several pieces of evidence are present to show that there was a high standard education system in the country, as some internationally reputed scholars were attracted to Sri Lankan educational institutions for continuing their higher studies. The main objective of ancient Buddhist education was to facilitate Buddhist monks to obtain a proper understanding of Tripitaka. However, some internationally reputed Buddhist monasteries like Abhayagiriya and Jethawana provided Buddhist monks with profane knowledge in line with Mahayana tradition. Later on, the Pirivenaeducation had been widely popularised among Sri Lankans, and it even opened Buddhist educational institutions to male-laities. Just before the colonisation of Sri Lanka, the Pirivenaeducation had been greatly performed and contributed widely to the establishment of an intelligent society in Sri Lanka. After the European colonisation, the entire Buddhist education system had been modified whilst raising some issues that prevented Buddhist monks from obtaining a properly planned education.
During the British colonisation of Sri Lanka, a proper and formal education system was introduced and was primarily influenced by Christian missions. Because of the less attention toward Buddhist education, the education among novice Buddhist monks was disrupted and was less recognised by the government policies. During the mid-twentieth century, some government interventions were made in improving Buddhist education among monks despite novice Buddhist monks facing some issues. From its implementation, the lay-education system has been systematically modified to reflect and respond to emerging needs of society, but the Pirivenaeducation has not been given adequate attention even to modify the syllabus appropriating it to the changing society. Therefore, in this research, we strived to understand how novice Buddhist monks reflect their positionality in the Buddhist community and to explore some of the problems encountered by novice Buddhist monks in their Prirvenaeducation.

We found that when laypeople become Buddhist monks, they are initially highly likely to encounter some problems adapting to a sacred life. Transiting to the Buddhist education system in Pirivenafrom a general school has been challenging as novice Buddhist monks have to modify their existing lifeworld practices and personas entirely to go along with a sacred life. Therefore, 
adapting to a new lifestyle whilst learning entirely different curricular with a new mode of thought has been challenging for many novice Buddhist monks. Besides, the internal arrangement of the Pirivenainstitution sometimes camouflages the internal mechanism from the outside community, which leads to developing a subculture that harms novice Buddhist monks in some cases. A subculture within the novel-Buddhist community is both encouraging and discouraging in some cases for novice Buddhist monks, as we demonstrated in the analysis. In addition, we understood that the existing syllabus of the Pirivenaeducation system is outdated and it is not responding to the emerging needs of society. Thus it has to be revised soon.

\section{Acknowledgement}

We are grateful to the editorial board for their continuous commitment and continuous support in publishing this paper and the anonymous reviewers for their generous and thoughtful comments. We also wish to acknowledge SusithNimantha, LakmiNilanka for their help and encouragement in improving and collecting data for this research. Lastly, we deeply appreciate the generosity and hospitality of all those who shared their stories with us.

\section{Disclosure Statement}

The authors reported no potential conflict of interest.

\section{REFERENCES}

Adhikari, A. (1993). Sri Lankawe sambhavya adhyapanaya ha maha sangana [The intellectual education of Sri Lanka and the Buddhist Sangha]. Colombo: Sri Dhara Publishers.

Amarasekara, S. (2017). Buddhist Meditation Monasteries in Ancient Sri Lanka. Journal of Arts and Humanities, 6(01), 59-68.

Andradi, D. (1967). English educated Ceylonese in the official life of Ceylon from 1865 to 1883. London: University of London

Bandaranayake, S. D. (2009). Sinhalese Monastic Architecture: The Viharas of Anuradhapura. New Delhi: Orient Blackswan.

Barua, T. (2014). Impact of Buddhist monasterybased education in the removal of poverty: $A$ comparative study of Sri Lanka and Bangladesh. Retrieved from http://www.icdv.net/2014paper/ws5_18_ en_Impact_of_Buddhist_monastery_bas ed_education_299406285.pdf

Basham, A. L. (2004). The Wonder that was India. London: Picador.

Braun, V., \& Clarke, V. (2006). Using thematic analysis in psychology. Qualitative Research in Psychology, 3(2), 77-101.

de Silva, C. (2019). The Education of Buddhist Monks in Sri Lanka: A Historical Review and Some Suggestions for Reform. Sri Lanka Journal of the Humanities, 42(1-2), 1.

de Silva, K. M. (1972). Sri Lanka (Ceylon) The new republican constitution. Law and Politics in Africa, Asia and Latin America, 5(3), 239-249.

de Silva, K. M. (1981). A History of Sri Lanka. Los Angelese: University California Press.

Dhammajothi, M. (2020). Challenges of Sri Lankan Buddhist scholarly tradition to create Sri Lanka as the hub of Pali and Buddhist education (pp. 1-11). pp. 1-11. Colombo: University of Colombo. Retrieved from https:/colomboarts.cmb.ac.lk/wpcontent/uploads/2014/11/RevDhammajothi.pdf

Hori, V. S. (1996). The Study of Buddhist Monastic Practice: Reflections on Robert Buswell's 'The Zen Monastic Experience. 
The Eastern Buddhist, 29(2), 239-261.

Jayaram, N. (1994, January 26). Religious revivalism and ethnic fratricide: The tragedy of Sri Lanka. Contributions to Indian Sociology, Vol. 28, pp. 163-168.

Karunarathna, W. (1974). Buddhism and Chirstianity in Ceylon. University of London, London.

Keerthirathne, W. K. D. (2020). A Study On Evolution Of Pirivena As An Educational Institute From Past To The Present In The History Of Traditional Education In Sri Lanka. International Journal of Humanities and Social Science Invention, 9(6), 41-45.

Kloppenborg, R. (1984). The Role of Buddhist Monks in Development Activities. Bijdragen Tot De Taal-, Land- En Volkenkunde, 140(1), 92-105.

Mendis, G. C. (1952). Ceylon under the British. Colombo: Educational Publsihers.

Morse, J. M., \& Clark, L. (2019). The Nuance of Grounded Theroy Sampling and the Pivotal Role of Theoretical Sampling. In A. Bryant \& K. Charmaz (Eds.), The Sage Handbook of Grounded Theory (2nd ed., pp. 145-166). London: SAGE Publication Ltd.

Pirivena Education Act. , Pub. L. No. 64 of 1979, 195 (1980). Sri Lanka.

Rahula, W. (1956). History of Buddhism in Ceylon: the Anuradhapura period, 3rd Century B.C. - 10th Century A.C. Colombo: Gunasena.

Rhea, Z. M. (2012). Mindful teaching: Laying the dharma foundations for buddhist education in Australia. International Education Journal, 11(1), 35-51.

Scott, D. (1996). Religion in colonial civil society: Buddhism and modernity in 19th-century Sri Lanka. Cultural Dynamics, 8(1), 7-23.

Smith, J. A., \& Osborn, M. (2015). Interpretative phenomenological analysis as a useful methodology for research on the lived experience of pain. British Journal of Pain, 9(1), 41-42.

Thapar, R. (1973). A History of India. England: Messrs Penguin Books.

Tong, A., Sainsbury, P., \& Craig, J. (2007).
Consolidated criteria for reporting qualitative research (COREQ): a 32-item checklist for interviews and focus groups. International Journal for Quality in Health Care, 19(6), 349-357.

Wangmo, S. (2016). The relationship between monastic and local communities: the example of Lhagang village in Kham MinyagChangements des relations entre communautés monastiques et locales: l'exemple de Lhagang au Kham Minyag. Études Mongoles Et Sibériennes, Centrasiatiques Et Tibétaines, 1(47), 1-13.

Wenzlhuemer, R. (2008). Christian Missionary Activity and Buddhist Response. In From Coffee to Tea Cultivation in Ceylon, 1880-1900 (pp. 271-295). Leiden: Brill. 